\title{
PEMETAAN TATA KELOLA TI DAN ANALISA FAKTOR PENGHAMBATNYA : STUDI KASUS PT BANK DNM, TBK
}

\author{
Alfian Nurdin \\ Program Studi Informatika \\ Fakultas Teknik Universitas Muhammadiyah Tangerang \\ Jl. Perintis Kemerdekaan 1/33 Cikokol Kota Tangerang \\ Alfian81@gmail.com
}

Fulfillment of the provision of accurate information and timely in the use, management, effectiveness and responsibility in the banking sector is a must.As a high industry regulation, then needed a good Governance to all sectors including in the field of information technology (it), particularly in the implementation of the principles of Good Corporate Governance.Research using the framework IT Governance as a method of analysis, namely: structure, process, the mechanisms of the relationship; Weill \& Ross; ITGI; and AS8015.Then the mapping of the results obtained will be formulated problems facing Banks DNM in it governance.The formulation of the problem is then mapped into a Fishbone Analysis solution is given and try using COBIT 4.1 Best Practice.From the results of this research are expected to Bank DNM can enhance the fulfillment of their needs in terms of information provision to support the implementation of the tasks and functions in the banking sector.

Keyword : IT Governance, Good Corporate Governance, COBIT 4.1

\section{Latar Belakang}

Seiring dengan perkembangan zaman, dunia bisnis saat ini tidak dapat dipisahkan lagi dari teknologi informasi. Teknologi informasi yang awalnya sebagai support dan mendukung operasional, secara bertahap sudah berubah menjadi key operational, high potential dan terakhir menjadi strategic (Mac Farlan) perusahaan untuk meningkatkan competitive advantage serta menjawab kebutuhan bisnis dalam memenuhi tuntutan pasar dan time to market. Untuk itulah dibutuhkan suatu sinergi yang kuat antara bisnis dan teknologi, agar terjadi keselarasan dan dapat selalu berjalan beriringan dalam meningkatkan pertumbuhan bisnis.
Sebagai salah satu contoh industri yang paling banyak bergantung teknologi informasi adalah perbankan. Disini keselarasan (alignment) antara strategi bisnis dan strategi teknologi informasi adalah suatu keharusan, terlebih kebutuhan untuk dapat memberikan data yang cepat, tepat dan akurat. Terlebih saat ini, dunia perbankan sudah mulai menggunakan teknologi komunikasi dan teknologi informasi menjadi tingkat persaingan yang kompetitif dalam memberikan kemudahan layanan, transaksi yang murah dan dapat dijangkau dimanapun berada dengan adanya electronic channel seperti ATM, SMS Banking, Internet Banking, Mobile Banking

Terlepas dari itu semua, dengan kemajuan teknologi informasi juga harus ditingkatkan keamanan dalam pelayanan terhadap nasabah, karena security merupakan faktor yang sangat 
krusial dalam industri ini. Untuk itulah teknologi informasi juga dapat digunakan untuk meningkatkan keamanan dalam bertransaksi seperti penggunaan PIN, encrypted, Pinpad, token dll. Faktor security memang tidak dapat dipisahkan dari kemajuan teknologi informasi.

Selain faktor security, peningkatan teknologi Informasi ini juga harus didukung dengan adanya suatu tata kelola TI (IT Governance) yang baik agar pemanfaatan teknologi lebih terarah, terstruktur serta optimal. Pemodelan IT Governance sendiri sebenarnya tidak mengindikasikan secara langsung bahwa perusahaan menerapkan suatu tata kelola perusahaan yang baik. Namun demikian dengan memodelkan suatu tata kelola IT akan menjadi langkah awal perusahaan dalam menuju tata kelola yang baik dan pada akhirnya dapat menghasilkan Good Corporate Governance. Sedangkan tantangan lain yang akan dihadapi adalah cara mengimplementasi model yang telah dibuat tersebut.

Fokus utama dalam tata kelola TI adalah TI harus memberikan dukungan terhadap bisnis sehingga menghasilkan value dan memitigasi resiko yang mungkin timbul. Tata kelola TI ini dapat dimulai dengan awareness pimpinan dan didukung dengan awareness oleh semua pihak. Yang lebih penting adalah semua harus sadar tentang peran dan akibat dari penerapan TI secara enterprise, mendefinsikan constrain tentang TI professional yang harus dioperasikan, diukur dan memahami risiko yang ada dan memberikan jaminan tentang pelaksanaannya.

Selain itu pentingnya strategi dan tata kelola TI terutama dalam perbankan yaitu menyangkut Risk Management, Core Banking Transformation, Managing the Data Infrastructure, Transaction Banking dan Selective Sourcing, financial Insights (2008). Tentunya tanpa tata kelola yang baik terhadap aspek-aspek TI tersebut akan menimbulkan resiko bagi perbankan itu sendiri dimana tingkat persaingan dan regulasi yang mengaturnya sangat ketat.

Sesuai dengan uraian di atas, penulis akan menguraikan tata kelola TI di Bank DNM
Indonesia dengan jumlah karyawan lebih dari 33.000 orang yang tersebar secara nasional, dan memiliki lebih dari 1400 cabang termasuk anak perusahaan lainnya. Selain itu juga terdapat bermacam electronic channel (lebih dari 14000 ATM termasuk jaringan mitra, SMS Banking, Internet Banking dan Call Center).

Untuk dapat memperoleh gambaran model tata kelola TI di Bank DNM INDONESIA, penulis akan menggunakan pendekatan beberapa model IT Governance yang sudah ada.

\section{Metodologi Penelitian}

Secara garis besar metodologi riset yang digunakan adalah studi kasus, dengan pendekatan hipotesa model. Studi ini meliputi analisa kontekstual dan mendalam tentang sesuatu yang berkaitan dengan situasi serupa yang ada di dalam organisasi lain. Sedangkan pendekatan hipotesa digunakan untuk memperoleh karakteristik atau fenomena yang terlihat dalam sebuah situasi dan ingin dapat dijelaskan secara lebih baik dengan memberikan riwayat mengenai faktor terkait (Sekaran, 2003).

Penelitian ini meliputi tiga tahapan, diatara lain tahapan input penelitian, tahapan proses penelitian dan yang terakhir tahapan output penelitian. Ditiap tahapan ada berbagai macam pekerjaan yang dilakukan untuk mendukung penelitian ini.

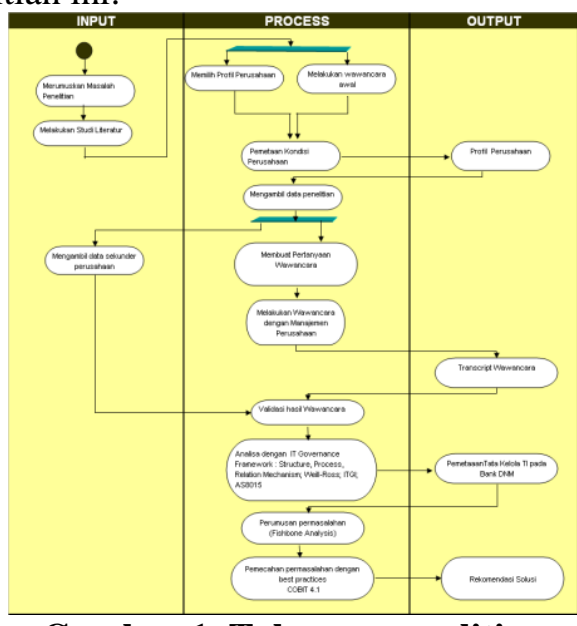

Gambar 1. Tahapan penelitian 
III. ANALISIS DAN PEMBAHASAN

A. Implementasi teknologi mutakhir New Core Banking System (NCBS) :

Bank DNM sebagai salah satu bank terbesar di Indonesia kembali menunjukkan komitmennya untuk meningkatkan pelayan kepada nasabah, dengan diterapkannya teknologi mutakhir New Core Banking System (NCBS) untuk menggantikan system International Comprehensive Banking System (ICBS) yang telah menjadi system core banking bank DNM saat ini. Dengan perubahan dari system ICBS ke NCBS, maka diharapkan Bank DNM akan lebih focus kepada nasabah dan memiliki fleksibilitas dalam menawarkan berbagai produk inovatif dari berbagai segmen bisnis melalui berbagai saluran distribusi yang didukung kapabilitas single view customer.

Mengingat kritikal dan skalanya yang Bank Wide, maka Sejumlah 80 orang pegawai lintas divisi (berbagai unit kerja) telah bergabung sebagai anggota tim program, dari vendornya sendiri I-Flex sendiri telah menugaskan tim yang beranggotakan lebih dari 30 orang khusus untuk mengerjakan program ini. Pelaksanaan Aplikasi system NCBS ini dibawah arahan NCBS Steering Committee yang dipimpin langsung oleh Wakil Direktur Utama dan beranggotakan Direktur

\section{B. Proses}

Bank DNM memiliki suatu pedoman dalam melaksanakan penyusunan inisiatif yaitu sesuai SE tentang Penyusunan Rencana Kerja dan Anggaran Perusahaan (RKAP) PT Bank DNM (Persero) Tbk. Tahun 2008 dengan Petunjuk Pelaksanaannya. Dalam penyusunan inisiatif dilakukan penyusunan yang berasal dari Top Down dan Bottom Up. Adapun usulan Top Down diawali melalui penyusunan Annual Strategic Business Plan (ASBP) untuk Business Unit maupun Annual Planning Supporting Plan (ASSP) untuk Corporate Center dan Shared
Teknologi Informasi sekaligus CIO, Direktur Operasional, Direktur keuangan.

Proyek NCBS merupakan kumpulan tahapan proyek yang terdiri dari :

1. Proyek Enterprise General Ledger (EGL) Adalah proyek yang ditujukan untuk mengimplementasikan EGL sehingga konsolidasi financial bank dapat ditampilkan melalui EGL.

2. Proyek SEMM

Adalah proyek yang ditujukan transformasi bisnis bagi operasi cabang SEMM serta mengimplementasikan Flexcube Core Banking System (NCBS)

3. Proyek Konvensional

Adalah proyek yang ditujukan untuk melakukan transformasi bisnis di cabang konvensional dan mengimplementasikan Flexcube NCBS

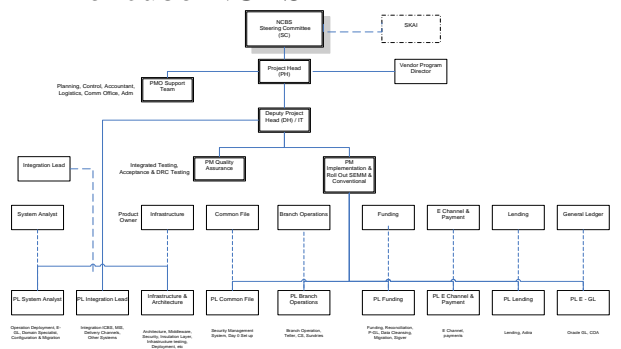

Gambar 3. Struktur Proyek NCBS

Services. Untuk proses secara Bottom-Up penyusunan dilakukan mulai dari unit kerja yang terendah. Usulan ini juga diikuti dengan usulan RKAP 2008 dari Group yang disampaikan kepada SPM Group dan harus mendapat persetujuan Direktur Bidang/EVP/Koordinator bidang yang membawahi Group yang bersangkutan. Proses penyusunan ini menempuh beberapa tahapan, dimana terdapat challenge session untuk masing-masing Group sebelum diajukan untuk memperoleh persetujuan Direksi dan pada akhirnya disebut dengan Rencana Kerja Anggaran dan Pendapatan. Secara keseluruhan inisiatif tersebut dapat disarikan dapat suatu IT Project Life Cycle seperti terlihat pada gambar 4 


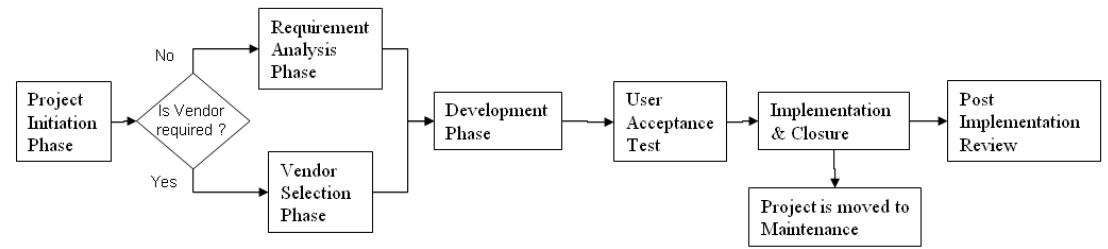

Gambar 4. IT Project Life Cycle (SDLC)

\begin{tabular}{|c|c|c|c|}
\hline Deliverables & Vendor Selection (only incase & Development & User Acceptance Test \\
\hline & of Vendor development) & Release Notes/Design Document & Technical Problem Report \\
\hline & KFI (optional) & I est Plan & Final DR Plan (for new \\
\hline Project Initiation & & Unit/SIT Specification & applications) \\
\hline Service Request Form & POC (optional) & Source Code & UAT sign-off \\
\hline Business Requirements Doc & SOW & Defect $\log$ (for Unit/SIT) & SLA \\
\hline Principal Approval & Functional Specification Doc & SIT Sign-oft & OLA \\
\hline & $\mathrm{I} 2 \mathrm{P}$ & $\begin{array}{l}\text { Acceptance Test Plan } \\
\text { Acceptance Test Specification }\end{array}$ & $\begin{array}{l}\text { Program Release Notice (if } \\
\text { changed after UAT) }\end{array}$ \\
\hline & Purchase Requisition Form & Program Release Notice (after & Change Request Form \\
\hline Requirement Analysis (only & PMP & SIT) & D Day checklist \\
\hline $\begin{array}{l}\text { mcase or BDI development) } \\
\text { Functional Specification Doc }\end{array}$ & Detail Plan & Operating Procedures Manual & \\
\hline Project Approval Memo & & Security Matrix & Implementation \& Closure \\
\hline $\mathrm{I} 2 \mathrm{P}$ & & User Authorization matrix & Production Assurance script \\
\hline Purchase Requisition Form & & Mantenance Manual & Implementation report \\
\hline $\begin{array}{l}\text { PMP } \\
\text { Detail Plan }\end{array}$ & & applications) & \\
\hline Detail Plan & & & Post-Implementation Review \\
\hline
\end{tabular}

Gambar 5. Deliverables dari SDLC IT

Penilaian nilai tambah investasi TI terhadap bisnis dilakukan dengan perhitungan break event point. Setelah proyek TI berakhir, dilakukan perbandingan antara hasil proyek dengan rancangan yang dibangun sebelumnya apakah sesuai atau tidak. Dari hasil yang sudah dilakukan, aplikasi- aplikasi yang dibangun atas permintaan internal, seperti bisnis-bisnis unit lainnya, selalu berhasil dan sukses di-deploy.

\section{Mekanisme Relasional}

Pengelolaan dan monitoring pencapaian vendor biasanya menggunakan Service Level Agreement Bank DNM untuk :

1. Sebagai standar pelayanan suatu unit kerja ataupun vendor dan sarana memperbaiki standar tersebut secara terus menerus.

2. Sebagai salah satu alat untuk mengukur kinerja unit kerja ataupun vendor.
3. Memotivasi unit kerja melakukan inovasi dan perbaikan dalam proses penyediaan service, sehingga service dapat disediakan lebih cepat dan dengan standar yang lebih baik.

Selain itu terdapat Operational Reliability secara ketat dikontrol, diukur dan dimonitor melalui SLA dan ditinjau kembali dalam annual maintenance renewals. Berikut adalah contoh SLA IT ke Bisnis Unit :

1. Availability Core Banking Systems, Payment System, Delivery Channel Systems (rata-rata $99.5 \%)$

2. Availability Support System \& Stand alone (rata-rata 99.5\%)

Untuk menjaga SLA IT ke Bisnis Unit tersebut maka dilakukan Maintenance Agreement dengan Vendor yang dimonitor oleh IT seperti yang bisa dilihat pada Tabel 1 
Tabel 1. SLA TI ke Vendor

\begin{tabular}{|l|l|l|}
\hline \multicolumn{3}{|c|}{ SLA IT to Vendor } \\
\hline \multicolumn{1}{|c|}{ Criticality System } & Down Time Tolerance & Minimum SLA \\
\hline Mission Critical System & $<5$ minutes & $99.99 \%$ \\
\hline Very Critical System & $<2$ hours & $99.72 \%$ \\
\hline Moderately Critical System & $<8$ hours & $98.88 \%$ \\
\hline Support System & $<24$ hours & $96.67 \%$ \\
\hline Standalone System & $<48$ hours & $93.33 \%$ \\
\hline
\end{tabular}

Menurut penulis secara keseluruhan proyek IT. Didukung dengan portal untuk mekanisme hubungan di Bank DNM sudah penyampaian informasi penting meskipun saat ini sangat baik dan terstruktur baik desain maupun baru beberapa group yang memanfaatkannya, penerapannya. Selain itu fungsi dari PMO, QM namun ke depan diharapkan semua dapat juga berperan penting didalamnya khususnya menggunakannya. Penyampaian informasi pada dalam pengelolaan dan pencapaian implementasi Bank DNM dapat berupa sebagai berikut :

Tabel 2. Relations Mechanism Bank DN M

\begin{tabular}{|c|c|c|}
\hline No & Jenis & Keterangan \\
\hline 1 & Memo & $\begin{array}{l}\text { Penyampaian Informasi/ permintaan antar department } \\
\text { dalam satu group }\end{array}$ \\
\hline 2 & Nota & $\begin{array}{l}\text { Penyampaian Informasi/ permintaan antar group di } \\
\text { Bank DNM }\end{array}$ \\
\hline 3 & Surat & $\begin{array}{l}\text { Penyampaian Informasi/ permintaan kepada pihak } \\
\text { ketiga diluar Bank DNM }\end{array}$ \\
\hline 4 & $\begin{array}{l}\text { Risalah Rapat / } \\
\text { MOM }\end{array}$ & Notulensi hasil keputusan rapat \\
\hline 5 & Surat Keputusan & Ketetapan tentang hasil pemutusan sesuatu \\
\hline 6 & Surat Edaran & $\begin{array}{l}\text { Pemberitahuan tentang informasi penting berkaitan } \\
\text { dengan semua proses, budaya, karyawan }\end{array}$ \\
\hline 7 & Email & Sarana komunikasi antar pegawai atau pihak eksternal \\
\hline 8 & Portal & $\begin{array}{l}\text { Media komunikasi dari management ke seluruh } \\
\text { internal karyawan }\end{array}$ \\
\hline
\end{tabular}

D. Weill \& Ross

Dalam modelnya, Weill \& Ross menggambarkan tentang lima hal penting yaitu IT Principle, IT Architecture, IT Infrastructure, Business Application Needs dan IT Investment. Model ini menggambarkan bagaimana proses usulan dan pengambilan

keputusan dari kelima hal penting tersebut. Dari hasil wawancara dan studi literatur, Model Weill
\& Ross di Bank DNM dengan pendekatan governance arrangement matrix dapat digambarkan sebagai berikut. 
Tabel 3 Governance Arrangements Matrix Bank DNM

\begin{tabular}{|c|c|c|c|c|c|c|c|c|c|c|c|}
\hline & \multicolumn{2}{|c|}{ IT Principles } & \multicolumn{2}{|c|}{ IT Architecture } & \multicolumn{2}{|c|}{$\begin{array}{c}\text { IT Infrastructure } \\
\text { Strategies } \\
\end{array}$} & \multicolumn{2}{|c|}{$\begin{array}{c}\text { Business } \\
\text { Application Needs }\end{array}$} & \multicolumn{2}{|c|}{ IT Investment } \\
\hline & & Input & Decision & Input & Decision & Input & Decision & Input & Decision & Input & Decision \\
\hline \multirow{6}{*}{ 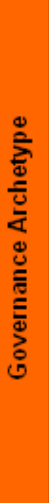 } & $\begin{array}{l}\text { Business } \\
\text { Monarchy }\end{array}$ & & $\begin{array}{l}\text { ITSC \& } \\
\text { BOD }\end{array}$ & & & & & & $\begin{array}{l}\text { ITSC \& } \\
\text { BOD }\end{array}$ & & $\begin{array}{l}\text { ITSC \& } \\
\text { BOD }\end{array}$ \\
\hline & \begin{tabular}{|c} 
IT \\
Monarchy \\
\end{tabular} & & & $\begin{array}{l}\text { CTO \& } \\
\text { GHIT }\end{array}$ & $\begin{array}{l}\text { ITSC \& } \\
\text { CTO }\end{array}$ & $\begin{array}{l}\text { CTO \& } \\
\text { GHIT }\end{array}$ & $\begin{array}{l}\text { ITSC \& } \\
\text { CTO }\end{array}$ & & & & \\
\hline & Feudal & & & & & & & & & & \\
\hline & Federal & & & & & & & & & & \\
\hline & Duopoly & $\begin{array}{c}\text { IT \& Unit } \\
\text { Bisnis } \\
\text { terkait }\end{array}$ & & & & & & $\begin{array}{c}\text { IT \& Unit } \\
\text { Bisnis } \\
\text { terkait }\end{array}$ & & $\begin{array}{c}\text { IT \& Unit } \\
\text { Bisnis } \\
\text { terkait }\end{array}$ & \\
\hline & Anarchy & & & & & & & & & & \\
\hline
\end{tabular}

Dari tabel diatas, terlihat bahwa hampir sebagian besar IT decision yang berhubungan dengan infrastruktur dan arsitektur diambil oleh CTO dan Group Head Of IT (GHIT) sehingga peranan IT sangat dominan disini, dalam Rapat IT Steering Commiteee sendiri juga dihadiri Direksi, dengan mendapat input dari pihak IT maupun unit bisnis terkait. Selain itu menurut penulis dapat disimpulkan bahwa di Bank DNM sudah terjadi sinergi antara IT dan bisnis, dimana dalam pengambilan keputusan penting terkait IT tetap melibatkan bisnis unit dan semua usulan inisiatif murni berasal dari bisnis unit. Namun demikian terdapat perbedaan simptom khususnya waktu awal masuknya perusahaan investasi asing ke DNM dimana untuk membangun suatu sistem yang baru dan terintegrasi, lebih ditekankan pola IT Driven, dimana semua usulan yang berkaitan dengan IT atau tidak, tetap diputuskan oleh IT. Hal ini disebabkan karena untuk mempermudah proses integrasi dan mewujudkan proses transformasi sistem dengan segera. Proses ini juga didukung oleh management IT, khususnya CTO pada waktu itu dimana CTO berperan seperti tangan besi dan mau tidak mau bisnis unit harus ikut. Hal ini sesuai dengan pernyataan dari IT - Data, Voice and Network (DVN) Head :

"CTO pasti terlibat dalam strategi bisnis, dan peranannya sangat kuat karena CTO sekarang merupakan satu paket dengan CEO DNM sebelumnya. Dan CEO tersebut sekarang masuk ke level direksi pada perusahaan induk DNM (Temasek Holding)'"

Dengan jaminan sistem yang dibangun akan establish dan mampu mendukung kebutuhan bisnis di masa depan. Seiring berjalannya waktu setelah sistem stabil, semua sudah berbalik seperti sekarang ini, dimana semua adalah business driven sesuai dengan pendapat dari IT - DVN Head :

"Di perusahaan terjadi pola business driven karena semua inisiatif berasal dari bisnis unit, sedangkan IT hanya memberikan dukungan dan analisa yang membantu bisnis unit dalam memilih aplikasi atau teknologi apa yang dapat diterapkan."

\section{E. ITGI Fokus Area}

Penulis akan memetakan dalam model ITGI yang terdiri dari Stakeholder Value Analysis, Strategic Alignment, IT Value Delivery, Risk Management, Performance Measurement dan IT Resources Management. Adapun teori ini melengkapi teori-teori yang lain dengan adanya Risk Management dan Value Delivery. Adapun gambaran ITGI focus area dapat dilihat pada gambar 4.8. 


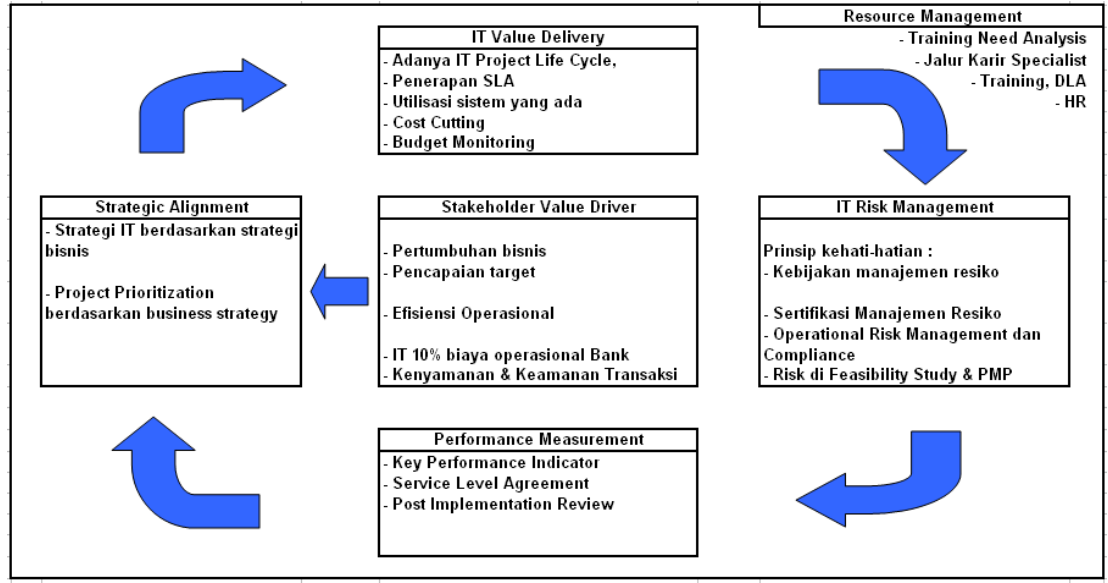

Gambar 6. ITGI Focus Area di Bank DNM

Pertama dari Stakeholder Value Analysis bank DNM adalah untuk memenuhi pertumbuhan bisnis, memenuhi pencapaian target, efisiensi operasional, Kenyamanan dan Keamanan Transaksi. Hal ini dipertegas dari hasil wawancara dari IT - DVN Head :

"Proses bisnis yang menjadi lebih singkat, aman, cepat dan pelayanan yang nyaman bagi nasabah baik eksternal maupun internal, serta IT bisa mensupport semua keinginan bisnis dan dalam pengembangan/maintenance/support aplikasi dapat lebih terstruktur dan mudah serta dapat menyesuaikan dengan time to market yang ada.."
Dan adanya fokus IT pada tahun berjalan sebagai berikut:

"Saat ini difokuskan pada efisiensi, baik pada pengadaan, maintenance, komunikasi dan semua yang berkaitan dengan Budget IT akan berdasarkan prioritas. Bisa dilakukan switching antar project tergantung prioritas, bahkan bisa project yang sebelumnya tidak terdaftar dam muncul mendadak bisa mendapat budget apabila prioritasnya memang tinggi.

\section{F. Australian Standard 8015}

Gambaran Model IT Governance berdasarkan AS8015 pada Bank DNM dapat dilihat pada gambar berikut :

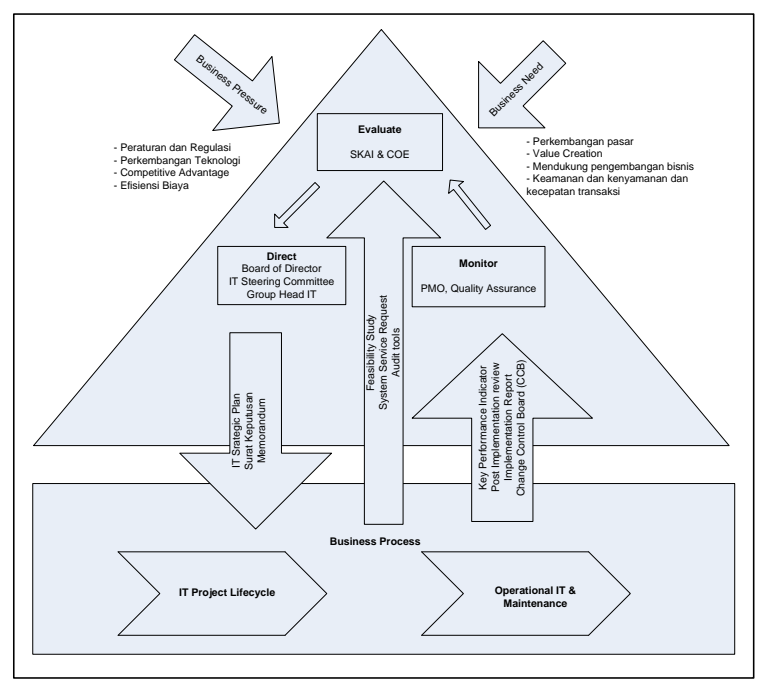

Gambar 7. AS8015 Framework Bank DNM 
Dari gambar 7 dapat dilihat bahwa business need yang mempengaruhi pembuatan IT Governance adalah untuk mengembangkan pasar, menciptakan nilai dan mendukung bisnis dapat berkembang. Selain itu juga untuk memberikan pelayanan yang nyaman dan aman seperti dalam kutipan berikut :

"Proses bisnis yang menjadi lebih singkat, aman, cepat dan pelayanan yang nyaman bagi nasabah baik eksternal maupun internal..."

Sedangkan untuk Business Pressure seperti yang tertera dalam dokumen yang ada bahwa Business Pressure Bank DNM adalah peraturan regulasi yang mengikat seperti Peraturan Bank Indonesia, BAPEPAM-LK, UU Perbankan maupun regulasi yang terkait secara spesifik pada produk perbankan seperti VISA, MasterCard ataupun peraturan internal lainnya. Selain itu didukung dengan perkembangan teknologi yang sangat pesat dan dipengaruhi perilaku konsumen yang kerap berubah sehingga menyebabkan persaingan yang ketat dengan kompetitor.

\section{Rumusan Tujuan}

Dari permasalahan-permasalahan yang sudah dirumuskan diatas, bagian ini akan menjabarkan tujuan yang akan dicapai ketika permasalahan tersebut dapat diatasi dan di mapping dengan proses-proses yang ada pada COBIT. Langkah kerja pemecahan permasalahan-permasalahan tersebut diilustrasikan pada gambar 9 dimana gambar oval menunjukkan proses yang dilakukan , sedangkan gambar kotak menunjukkan output yang akan dihasilkan. Perumusan pemecahan permasalahan yang dihasilkan merupakan sebuah rekomendasi solusi berdasarkan best practices COBIT, untuk penerapan di perusahaan dapat dilakukan penyesuaian-penyesuaian sesuai kebutuhan dan lingkungan internal.

\section{H. Rumusan Permasalahan}

Analisa permasalahan pengelolaan TI yang ada pada DNM diilustrasikan pada diagram tulang ikan (Fishbone Diagram) pada gambar 8 dibawah. Diagram Tulang ikan pada faktor permasalahan dikelompokkan dengan secara struktur, proses dan mekanisme relasional.

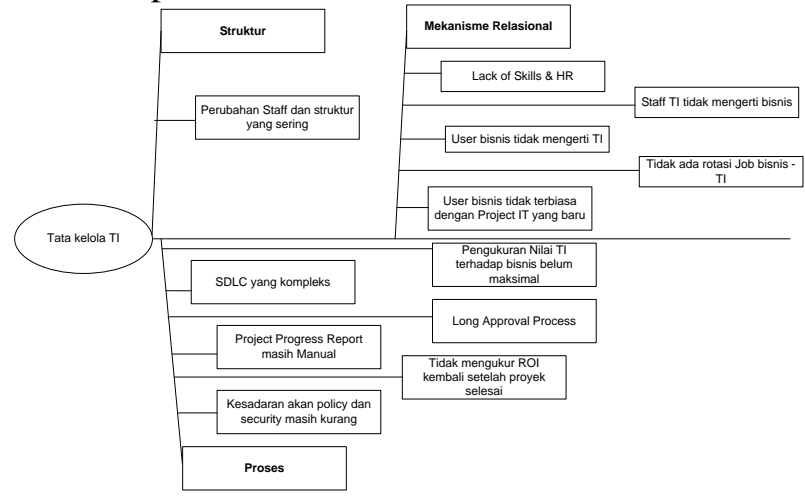

Gambar 8. Diagram Fishbone permasalahan Tata Kelola TI di Bank DNM

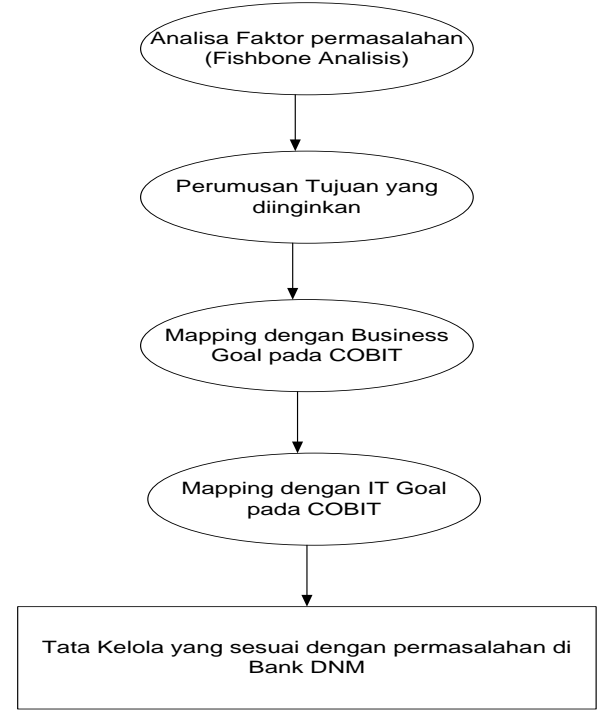

Gambar 9. Proses perumusan pemecahan masalah Bank DNM 
Tabel 3. Perumusan Tujuan pemecahan masalah Bank DNM

\begin{tabular}{|c|c|c|c|}
\hline No & Faktor Permasalahan & Tujuan Pemecahan Masalah & $\begin{array}{l}\text { Tujuan } \\
\text { Bisnis } \\
\text { COBIT }\end{array}$ \\
\hline 1 & Long Approval Process & $\begin{array}{l}\text { Efisiensi proses pada persetujuan yang dibutuhkan } \\
\text { dalam organisasi }\end{array}$ & 14,16 \\
\hline 2 & $\begin{array}{l}\text { Perubahan staff dan } \\
\text { struktur yang sering }\end{array}$ & $\begin{array}{l}\text { Penyesuaian terhadap struktur organisasi } \\
\text { berdasarkan best practices bagi perusahaan dan } \\
\text { expertise pada masing-masing bidang }\end{array}$ & 14,17 \\
\hline 3 & $\begin{array}{l}\text { Pengukuran Nilai TI } \\
\text { terhadap bisnis belum } \\
\text { maksimal }\end{array}$ & $\begin{array}{l}\text { Terdapat standar pengukuran TI kepada bisnis } \\
\text { sehingga value yang dihasilkan dapat maksimal }\end{array}$ & 1 \\
\hline 4 & SDLC yang kompleks & $\begin{array}{l}\text { Penyederhanaan SDLC tanpa mengurangi urgensi } \\
\text { masing-masing proses }\end{array}$ & 7,16 \\
\hline 5 & $\begin{array}{l}\text { Project Progress Report } \\
\text { masih Manual }\end{array}$ & $\begin{array}{l}\text { Pembuatan Sistem Report online dengan basis data, } \\
\text { sehingga memudahkan tracking status Project }\end{array}$ & 15 \\
\hline 6 & $\begin{array}{l}\text { Tidak mengukur ROI } \\
\text { kembali setelah proyek } \\
\text { selesai }\end{array}$ & $\begin{array}{l}\text { Terdapat pengukuran setelah proyek selesai } \\
\text { sehingga dapat menjadi masukan pada perencanaan } \\
\text { TI dan memaksimalkan investasi }\end{array}$ & 1 \\
\hline 7 & $\begin{array}{l}\text { Kesadaran akan Policy dan } \\
\text { Security masih kurang }\end{array}$ & $\begin{array}{l}\text { Meningkatkan awareness akan pentingnya policy } \\
\text { dan security pada perbankan, serta melalui training } \\
\text { dan aturan yang lebih mengikat }\end{array}$ & $2,12,13$ \\
\hline 8 & Lack of Skills \& HR & $\begin{array}{l}\text { Perekrutan dan peningkatan kemampuan melalui } \\
\text { training yang lebih intensif }\end{array}$ & 15,17 \\
\hline 9 & $\begin{array}{l}\text { Staff TI tidak mengerti } \\
\text { bisnis }\end{array}$ & $\begin{array}{l}\text { TI harus lebih mengerti bisnis agar bisa } \\
\text { mempercepat proses pengembangan model bisnis } \\
\text { yang lebih baik }\end{array}$ & 9 \\
\hline 10 & $\begin{array}{l}\text { User bisnis tidak Mengerti } \\
\text { TI }\end{array}$ & $\begin{array}{l}\text { TI harus bisa menjadi enabler bagi bisnis dan } \\
\text { memudahkan proses kerja mereka }\end{array}$ & 14 \\
\hline 11 & $\begin{array}{l}\text { Tidak ada rotasi Job Bisnis } \\
\text { - TI }\end{array}$ & $\begin{array}{l}\text { Sharing knowledge antara TI dan bisnis lebih } \\
\text { intensif agar dapat saling mengerti kebutuhannya }\end{array}$ & 14 \\
\hline 12 & $\begin{array}{l}\text { User bisnis tidak terbiasa } \\
\text { dengan Project TI yang } \\
\text { baru }\end{array}$ & $\begin{array}{l}\text { Edukasi dan pengenalan dan pemilihan project } \\
\text { harus melibatkan bisnis karena sangat penting } \\
\text { untuk keberhasilan project itu sendiri }\end{array}$ & 4,7 \\
\hline
\end{tabular}

Keterangan nomor tujuan bisnis pada tabel 5.1 :

1. (1) Menyediakan ROI yang baik pada investasi IT-Enabled business

2. (2) Mengelola keterhubungan resiko antara bisnis dengan TI

3. (7) Tangkas dalam merespon kebutuhan bisnis yang berubah.

4. (9) Menggali informasi yang reliable dan berguna untuk pengambilan keputusan strategis
5. (10) Meningkatkan dan memelihara fungsi bisnis proses.

6. (11) Biaya proses yang lebih rendah

7. (12) Menyediakan kepatuhan pada hukum, regulasi dan kontrak.

8. (13) Menyediakan kepatuhan terhadap kebijakan internal

9. (14) Mengelola perubahan bisnis

10. (15) Meningkatkan dan mengelola produktifitas operasional dan staff 
11. (17) Memperoleh dan mengelola orangorang yang mempunyai motivasi dan kemampuan

Dari perumusan tujuan bisnis COBIT yang didapat maka didapatkan tujuan TI yang sudah dimapping oleh COBIT yang sesuai. Pada tujuan
TI COBIT yang sudah tersedia oleh COBIT, dilakukan lagi penyesuaian terhadapnya. Penyesuain tujuan TI pada COBIT yang disesuaikan denga faktor permasalahan yang ingin diselesaikan, dimapping pada Tabel 4 Angka pada bagian "Tujuan TI COBIT" yang disesuaikan adalah nomor IT Goals.

Tabel 4. Perumusan Tujuan TI Bank DNM

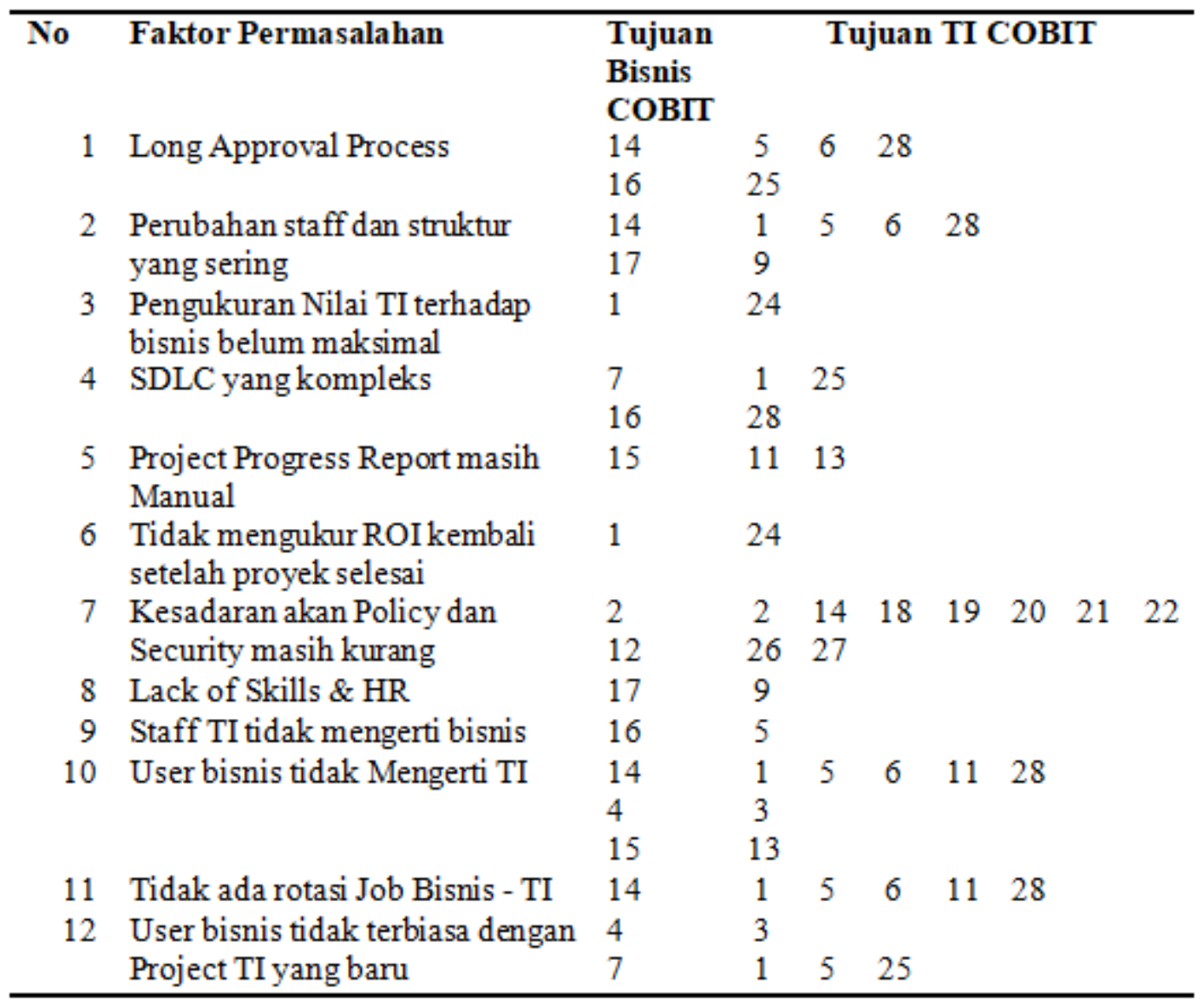

Keterangan nomor tujuan COBIT yang disesuaikan pada table 4:

1. (1) Merespon pada kebutuhan-kebutuhan bisnis dalam keselarasan dengan strategi bisnis

2. (2) Merespon pada kebutuhan-kebutuhan pengelolaan yang sejalan dengan arahan board.

3. (4) Optimalisasi kegunaan informasi
4. (5) membuat ketangkasan dalam TI

5. (6) Mendefinisikan bagaimana fungsi bisnis dan kebutuhan-kebutuhan control diartikan dalam solusi otomatis yang efektif dan efisien.

6. (7) memperoleh dan mengelola sistem aplikasi yang terintegrasi dan terstandarisasi. 
7. (8) Memperoleh dan mengelola Infrastruktur TI yang terintegrasi dan terstandarisasi.

8. (9) Memperoleh dan mengelola kemampuan TI yang merespon pada strategi TI

9. (11) Memastikan integrasi dari aplikasiaplikasi kedalam proses bisnis

10. (12) Memastikan transparansi dan pengertian tentang IT Cost, Keuntungan, Strategi, Kebijakan dan service level

11. (13) Memastikan penggunaan dan kegunaan yang tepat dari solusi aplikasi dan teknologi.

12. (14) Memperhitungkan dan mengamankan aset TI

13. (15) Mengoptimasi infrastruktur TI, Sumber daya dan kapabilitas.

14. (17) Mengamankan hal yang sudah didapat dari objektif TI

15. (18) Membangun kejelasan dari dampak bisnis terhadap resiko pada objektif TI dan sumber dayanya.

16. (19) Memastikan informasi yang kritis dan rahasia dapat dijaga dari yang tidak punya akses terhadapnya.

17. (20) Memastikan transaksi bisnis dan pertukaran informasi yang terotomatisasi dan dapat dipercaya.

18. (21) Memastikan layanan TI dan infrastrukturnya dapat bertahan dan memulihkan diri dari kesalahan akibat error, kesengajaan ataupun bencana.

19. (22) Memastikan minimal impact terhadap bisnis ketika terjadi gangguan ataupun perubahan di layanan TI

20. (24) Meningkatkan efisiensi dari pengeluaran TI dan kontribusinya kepada keuntungan bisnis.

21. (25) Mennyelesaikan project sesuai waktu dan budget, dan memenuhi kualitas standar.

22. (26) Mengelola integritas dari informasi dan pengelolaan infrastruktur.

23. (27) Memastikan TI mematuhi hukum, regulasi dan kontrak

24. (28) Memastikan bahwa TI menunjukkan kualitas layanan yang efisiensi dari biaya, pengembangan yang berkelanjutan dan siap dalam menghadapi perubahan di masa depan.

Dari perumusan tujuan TI COBIT yang didapat maka akan didapatkan proses-proses TI yang harus dijalankan sesuai dengan panduan COBIT. Pada proses TI COBIT yang sudah tersedia oleh COBIT, dilakukan lagi penyesuaian terhadapnya. Penyesuaian proses-proses TI pada COBIT yang disesuaikan dengan faktor permasalahan yang ingin diselesaikan, dimapping pada tabel 5. Kode pada bagian "Proses TI COBIT" yang disesuaikan adalah kode proses COBIT.

Tabel 5. Perumusan proses-proses TI Bank DNM

\begin{tabular}{llccc}
\hline No & Faktor Permasalahan & $\begin{array}{c}\text { Tujuan TI } \\
\text { COBIT }\end{array}$ & Proses TI COBIT \\
1 & Long Approval Process & 5 & PO4 & \\
& & 6 & AI6 & \\
& & 25 & PO8 & \\
2 & 28 & ME1 & ME4 \\
& Perubahan staff dan struktur & 1 & PO4 & AI6 \\
& yang sering & 5 & PO7 & \\
& 9 & AI5 & \\
3 & 28 & ME4 & \\
Pengukuran Nilai TI & 24 & PO5 & DS6 \\
& terhadap bisnis belum & & & \\
& maksimal & & & \\
\hline
\end{tabular}




\begin{tabular}{|c|c|c|c|c|c|c|c|c|c|c|}
\hline \multirow[t]{3}{*}{4} & \multirow[t]{3}{*}{ SDLC yang kompleks } & 1 & & $\mathrm{PO} 4$ & & & & & & \\
\hline & & 25 & & PO8 & & & & & & \\
\hline & & 28 & & ME4 & & & & & & \\
\hline 5 & $\begin{array}{l}\text { Project Progress Report } \\
\text { masih Manual }\end{array}$ & 11 & & AI7 & & & & & & \\
\hline 6 & $\begin{array}{l}\text { Tidak mengukur ROI } \\
\text { kembali setelah proyek } \\
\text { selesai }\end{array}$ & 24 & & PO5 & DS6 & & & & & \\
\hline \multirow[t]{6}{*}{7} & Kesadaran akan Policy dan & 2 & & ME4 & & & & & & \\
\hline & Security masih kurang & 14 & & PO9 & DS5 & DS9 & DS12 & ME2 & & \\
\hline & & 19 & & PO6 & DS11 & & & & & \\
\hline & & 21 & & DS13 & & & & & & \\
\hline & & 22 & & AI6 & & & & & & \\
\hline & & 27 & & ME3 & & & & & & \\
\hline 8 & Lack of Skills \& HR & 9 & & PO7 & AI5 & & & & & \\
\hline 9 & $\begin{array}{l}\text { Staff TI tidak mengerti } \\
\text { bisnis }\end{array}$ & 5 & & PO4 & PO7 & & & & & \\
\hline \multirow[t]{4}{*}{10} & User bisnis tidak Mengerti TI & & 1 & & PO4 & DS1 & ME1 & & & \\
\hline & & & 3 & & DS7 & DS8 & DS10 & & & \\
\hline & & & 13 & & PO6 & & & & & \\
\hline & & & 28 & & ME4 & & & & & \\
\hline \multirow[t]{3}{*}{11} & Tidak ada rotasi Job Bisnis - TI & & 1 & & $\mathrm{PO} 4$ & AI6 & & & & \\
\hline & & & 5 & & PO7 & & & & & \\
\hline & & & 28 & & ME4 & & & & & \\
\hline \multirow[t]{3}{*}{12} & User bisnis tidak terbiasa & & 1 & & $\mathrm{PO} 4$ & PO10 & DS1 & & & \\
\hline & dengan Project TI yang baru & & 3 & & PO8 & $\mathrm{AI} 4$ & DS7 & DS8 & DS10 & DS13 \\
\hline & & & 5 & & PO7 & & & & & \\
\hline
\end{tabular}

Keterangan kode dibagian proses-proses COBIT yang disesuaikan pada table 5.3:

1. PO4 : Mendefinisikan proses-proses TI, organisasi dan hubungan

2. PO5 : Mengelola investasi TI

3. PO6 : Mengkomunikasikan Tujuan dan arah manajemen

4. PO7 : Mengelola sumber daya manusia TI

5. PO8 : Mengatur Kualitas

6. PO9 : Memperkirakan dan mengatur Resiko TI

7. PO10 : Mengatur Proyek

8. AI4 : Menjalankan operasi dan penggunaan.

9. AI5 : Mengadakan sumber daya TI

10. AI6 : Mengatur Perubahan
11. AI7 : Menginstall dan memberikan solusi dan perubahan

12. DS1 : Menetapkan dan mengatur service level

13. DS5 : Memastikan keamanan sistem

14. DS6 : Mengidentifikasi dan mengalokasi biaya.

15. DS7 : Mengedukasi dan memberikan training kepada user.

16. DS8 : Mengelola layanan dan permasalahan.

17. DS9 : Mengelola informasi

18. DS10 : Mengelola permasalahan

19. DS11 : Mengatur Data

20. DS12: Mengatur lingkungan Fisik

21. DS13 : Mengatur operasional 
22. ME1 : Monitor dan evaluasi pelaksanaan TI

23. ME2 : Monitor dan evaluasi kontrol internal

24. ME3 : Memastikan kepatuhan dengan

25. ME4 : Meyediakan pengelolaan TI persyaratan eksternal

\section{Saran Perbaikan Pengelolaan TI}

Dari proses perumusan masalah hingga mendapatkan proses-proses TI dari COBIT maka didapat saran perbaikan pengelolaan TI yang dapat dikembangkan sesuai dengan kondisi perusahaan DNM. Bagian ini akan menjelaskan bagaimana proses-proses yang dipilih, diharapkan dapat menanggulangi permasalahan yang ada. Pengelompokan dilakukan berdasarkan proses TI COBIT yang sudah disesuaikan dan diilustrasikan pada Tabel 6

Tabel 6. Mapping Proses COBIT terhadap permasalahan Bank DNM

\begin{tabular}{|c|c|c|}
\hline No & Proses TI COBIT & $\begin{array}{c}\text { Faktor } \\
\text { Permasalaha }\end{array}$ \\
\hline 1 & PO4 : Mendefinisikan proses-proses TI, organisasi dan hubungan & $1,2,4,9,10,11$, \\
\hline 2 & PO5 : Mengelola investasi TI & 3,6 \\
\hline 3 & PO6 : Mengkomunikasikan Tujuan dan arah manajemen & 7,10 \\
\hline 4 & PO7 : Mengelola sumber daya manusia TI & $2,8,11,12$ \\
\hline 5 & PO8 : Mengatur Kualitas & $1,4,12$ \\
\hline 6 & PO9 : Memperkirakan dan mengatur Resiko TI & 7 \\
\hline 7 & PO10 : Mengatur Proyek & 12 \\
\hline 8 & AI4 : Menjalankan operasi dan penggunaan & 12 \\
\hline 9 & AI5 : Mengadakan sumber daya TI & 2,8 \\
\hline 10 & AI6 : Mengatur Perubahan & $1,7,11$ \\
\hline 11 & AI7 : Menginstall dan memberikan solusi dan perubahan & 5 \\
\hline 12 & DS1 : Menetapkan dan mengatur service level & 10,12 \\
\hline 13 & DS5 : Memastikan keamanan system & 7 \\
\hline 14 & DS6 : Mengidentifikasi dan mengalokasi biaya & 3,6 \\
\hline 15 & DS7 : Mengedukasi dan memberikan training kepada user & 10,12 \\
\hline 16 & DS8 : Mengelola layanan dan permasalahan & 10,12 \\
\hline 17 & DS9 : Mengelola informasi & 7 \\
\hline 18 & DS10 : Mengelola permasalahan & 10,12 \\
\hline 19 & DS11 : Mengatur Data & 7 \\
\hline 20 & DS12: Mengatur lingkungan Fisik & 7 \\
\hline 21 & DS13 : Mengatur operasional & 7,12 \\
\hline 22 & ME1 : Monitor dan evaluasi pelaksanaan TI & 1,10 \\
\hline 23 & ME2 : Monitor dan evaluasi kontrol internal & 7 \\
\hline 24 & ME3 : Memastikan kepatuhan dengan persyaratan eksternal & 7 \\
\hline 25 & ME4 : Menyediakan pengelolaan TI & $1,2,4,7,10,11$ \\
\hline
\end{tabular}




\section{KESIMPULAN}

Dari hasil penelitian diperoleh bahwa implementasi IT Governance di Bank DNM pada umumnya sudah baik namun memang belum terstruktur dan terdokumentasi dengan baik, terbukti dibandingkan dengan studi kasus perbankan yang lain juga tidak terlalu jauh berbeda, meskipun terdapat beberapa kekurangan, mengingat Bank DNM baru 5 tahun terakhir keluar dari fase BPPN dan mulai menerapkan prinsip-prinsip Good Corporate Governance $(G C G)$ serta tekanan regulasi yang lebih ketat dari Bank Indonesia. Proses kerja yang dilakukan adalah dengan memetakan kondisi perusahaan pada framework pengelolaan TI yang merupakan kombinasi Struktur, Proses, dan Mekanisme Relasional menurut Grembergen, De Haes \& Guldentops; Model Weill \& Ross; ITGI focus Area; dan Australian Standard AS8015 sehingga dapat memperkuat analisa penulis terhadap implementasi IT Governance di Bank DNM.

Dari hasil pemetaan kemudian coba dilakukan analisa terhadap permasalahan-permasalahan yang ada untuk dicari solusinya berdasarkan best practice COBIT 4.1. Dihasilkan rekomendasi solusi menggunakan 25 kontrol pada COBIT untuk menjawab 12 permasalahan yang dapat didefinisikan. Penulis melihat sebenarnya dengan menerapkan prinsip-prinsip Tata kelola TI yang lebih baik dari sekarang dan terstruktur secara lebih formal, maka permasalahan yang ada dapat dikurangi bahkan dihilangkan meski tidak semuanya. Mekanisme Lesson learned juga lebih dimaksimalkan dengan melakukan dokumentasi yang baik dan komunikasi yang lebih intensif dengan unit kerja atau bisnis lain dapat memaksimalkan peran TI sebagai enabler sekaligus memberikan Nilai lebih dan meminimalisir resiko bagi Bank DNM.

Contoh konkret penerapan prinsip Tata kelola yang baik pada Bank DNM adalah implementasi sistem core banking baru yang akan menjadi tonggak sejarah di Bank DNM. Tambahan dukungan faktor enabler IT management yang sangat mengerti TI serta adanya IT Leadership bukan tidak mungkin, proses perbaikan akan terus menerus dilakukan untuk pencapaian IT Governance secara menyeluruh yang lebih baik.

\section{REFERENSI}

AS8015. "Australian Standard 8015, Section 2 : Overview of Framework for Good Corporate Governance of ICT." 2005.

COBIT Steering Committee and the IT Governance Institute, COBIT 4.1 Executive Summary, IT Governance Institute, 2007.

COBIT Steering Committee and the IT Governance Institute, COBIT 4.1 Framework, IT Governance Institute, 2007.

Financial Insights, "Top 10 Strategic in APAC Banking for 2008 : The Return of the Customer", Jan 2008

Grembergen, W Van, Information strategies and tactics for Information technology governance, Idea Group Publishing, 2003.

Haas, Steven D, dan Win Van Grembergen. "IT Governance Structures, Process and Relational Mechanism: Achieving IT/ Business Alignment in Major Belgian Financial Group.” 2005.

ITGI. "Board Briefing on IT Governance (2nd Edition)." 2000. ITGI. "Enterprise Value Governance of IT Investment: ING Case Study.” 2006.

Kartika, Ikka. "Pemetaan IT Governance Dalam High Regulated Industry pada Studi Kasus PT Bank XYZ (persero), TBK”. 2007. 
Luftman, Jerry, dan Raymond \& Brier Tom Papp. "Enablers \& Inhibitors of Business IT Alignment.” 2002.

Porter , E.Michael, Competitive Strategy, 1998.

Prawira, B Albert. "Pemetaan Model Tata Kelola Teknologi Informasi yang Menunjang Strategi dan Visi Organisasi

di Indonesia: Studi Kasus Bank swasta $D A " .2007$.

Sekaran, Uma. Research Methods For Business. John Willey \& Sons, 2003.

Spirit Danamon. "Satuan Kerja Audit Intern(SKAI)", Media Komunikasi dan Informasi, Edisi 4/2007
Spirit Danamon. "Tingkatkan Layanan Dengan Teknologi Mutakhir NCBS”, $\quad$ Media Komunikasi dan Informasi, Edisi 3/2007

Spirit Danamon. "Center of Operational Excellence (COE)”, Media Komunikasi dan Informasi, Edisi 1/2008

Tzu, Sun, The Art of War, http://en.wikipedia.org, written in the $6^{\text {th }}$ century BC, 2007.

Weills, Peter, dan Jeanne W. Ross. IT Governance : How Top Performers Manage IT Decision Rights for Superior Results. Boston, Massachusetts : Harvard Business School Press, 2004. 